\title{
A ANDRÉS SÁNCHEZ ROBAYNA, POETA DEL ESPÍRITU DE LA MATERIA
}

Juan Antonio MASOLIVER RÓDENAS

Poetas de la esencia

que afirman la vida.

Poetas de la vida

que niegan la esencia.

El que vivió en Londres

y ahora pasea en verano

con un paraguas negro

comprado en Smith and Bros

apenas sale de casa

para seguir siendo inglés.

El niño de entonces

con un flabiol en la boca

intentando inventar una patria.

Escribieron en latín

-no nosotros, hijos de la ignorancia-

antes de hacerlo en provenzal

o en el catalán de J. V. Foix,

para llegar a la esencia luminosa

de la poesía de Sánchez Robayna.

$\mathrm{Y}$ entonces, en una noche

sin amanecer, en la pesadilla

de las palabras que invento

con la osadía de los poetas audaces,

decido escribir

lo que pasa en la calle:

la carroza de los muertos,

de los que lloran el fin 
de la poesía de la esencia

y que, con la soga en la mano,

buscan el árbol más doloroso

del invierno.

(Poema inédito) 